doi: 10.52370/TISC21450PR

\title{
TOURIST DEVELOPMENTS IN COVID PANDEMIC CONDITIONS ON THE EXAMPLE OF ISTRIA COUNTY, CROATIA
}

\author{
Pavlo Ružićc ; Dragoljub Amidžić ${ }^{2}$
}

\begin{abstract}
The occurance of the COVID pandemic in 2020 caused major health problems to the population and the world economy, an economic crisis with an evident decline in financial and productive power, rising unemployment and falling living standards. Unemployment and declining living standards were reflected in tourism trends, which were largely absent in such conditions. Following the stated assumptions, the purpose and goal of this paper is to investigate the impact of the COVID pandemic in the segments of tourist trends on the example of the Istrian tourist destination. The research was conducted from a theoretical and empirical point of view. Theoretical research is focused on finding relevant insights into the impact of the COVID pandemic on tourism trends. Empirical research based on statistical indicators will determine the quantitative impact of the pandemic on tourism trends.
\end{abstract}

Key Words: COVID pandemic, tourism trends, global economy, economic crisis, Istria County

JEL classification: Z3, Z32, Z39

\section{Introduction}

Globalization movements have opened up organizational, economic, and numerous other processes. In these complex processes, numerous bodies have emerged that directly and indirectly conduct the development of entire economies, including tourism at all spatial and economic levels.

\footnotetext{
1 Pavlo Ružić, PhD, scientific adviser, Institute for Agriculture and Tourism Poreč, Croatia, 0915558011, pavlo@iptpo.hr

2 Dragoljub Amidžić, PhD, prof. H S, "Baltazar Adam Krčelić", Zaprešić, Croatia, 098221131,dragoljub.amidzic@gmail.com
} 
During 2020, the global economy was hit by the COVID pandemic, which caused a global economic crisis with disastrous consequences in all structures of the economy, including tourism. The global economic crisis caused by the COVID pandemic has threatened the financial and productive power of the global economy, which had a negative impact on investments, employment and peoples living standards. Decline in financial power had an unfavorable effect on investments in tourism, so there was no construction of new capacities nor projects aimed at improving the quality of the existing ones. The decline in production in most economic activities increased unemployment, which in turn led to a decline in living standards of the population, ultimately reflected on the reduction of tourist trends in terms of volume and structure.

Following the mentioned indications, the authors in this paper investigate the impact of the global economic crisis caused by the COVID pandemic on tourist traffic (tourists and overnight stays), using Istria as an example.

The obtained data from the research will be used to confirm or reject the hypotheses which assume that the overall tourist trends observed through tourist and overnight traffic have declined; that tourist traffic from neighbouring countries has declined more slowly than that of tourists from other countries; that the choice of residence is scewed towards rural areas; while the preferrence is tilted towards the selection of smaller and detached accommodation facilities.

\section{The emergence of the COVID pandemic and its impact on the global economy and tourism}

Corona virus appeared in December 2019 in the city of Wuhan, China and from January 2020, it began to spread rapidly to all parts of the world.

The first case of coronavirus outside China was recorded on January 30, 2020. As the coronavirus spread rapidly to other countries, the World Health Organization declared a global pandemic, classifying it as a "public health threat of international importance, due to the speed of the epidemic and the large number of unknowns about the new virus."

The first case of coronavirus infection in Croatia was recorded on February 25,2020 , and measures of the health package for the control of coronavirus were adopted, consisting of:

- social distancing measures; 
- closure of schools and universities;

- postponement or cancellation of all types of public events (artistic, sports, etc.);

- mass testing and monitoring of infection.

While these measures were succesful in reducing infection, they have also, by limiting human activity (containment), had significant economic costs. Never before have such measures been introduced (i.e. a ban on work, travel and the like). Even if the suspension did not last longer than one or two months, in 2020 there was a serious drop in GDP in many countries. The consequences of this pandemic on the economy are reflected in reduced sales, work limits, and thus an increase in the number of unemployed due to layoffs, while bringing into question the survival of other segments of the economy such as airports, banking system, small and medium catering companies and the like. Unlike the crisis that occurred in 2008 , and the same had significant consequences for the real economy, the crisis caused by the COVID pandemic had far greater consequences. This crisis has had an impact on the import and export of goods, all levels of business, the operation of catering facilities, air transport and the like.

Most countries in the world have introduced collective quarantine, while closing state borders. Epidemiological measures that were in force in the Republic of Croatia include:

- Closing of state borders;

- Obligation to wear protective masks and gloves;

- Ban on movement from county to county, and from city to city exclusively from e-pass;

- Limited number of people staying in a certain area;

- Ban on work in catering facilities;

- Social distancing measures.

These measures were introduced in March of 2020 and were maintained until the end of May, when the first wave of infection was brought completely under control. Measures of limited number of people staying in a certain area remain in force for prevention, whereby the measure of social distance of 1.5 meters, regular disinfection of rooms, regular disinfection of hands, wearing protective masks indoors must be respected. Furthermore, it is important to point out that the European Commission is also taking a number of measures as a common European response to the coronavirus pandemic. Decisive measures are being taken to strengthen the 
public health sector and mitigate the socio-economic consequences in all EU Member States. Likewise, all the means at our disposal are being mobilized to help Member States coordinate national responses and provide objective information on the spread of the virus and effective efforts to combat it. In these times of crisis, countries, regions and cities in the European Union help neighbors and those most in need: they donate protective equipment such as masks, provide cross-border treatment for sick patients and bring home blocked citizens abroad.

\section{Tourist traffic in the conditions of the crown of the pandemic and the global economic crisis}

Strong changes in the organization and management of world tourism have taken place since the 1990s. In the context of these changes, tourism demand, consumption and commercialization are developing dynamically. The complexity of the entire organizational process in international tourism is manifested in the interaction of many participants, which includes the integration of institutions and their functioning.

(Aramberri, 2008) points out that unexpected crises (September 11, 2001, Iraq and SARS 2003, Tsunami 2004, Avian Influenza 2005) have significantly affected tourism. Although international tourism developed extremely dynamically in the middle of the last century, 1982, 2001, and 2003 saw a decline in tourist arrivals. The decline in tourist arrivals of $0.4 \%$ in 1982 was caused by the recession in the world economy, caused by the oil crisis, and in 2001 the decline of $-0.5 \%$ occurred due to the terrorist attack on the United States, while in 2003 the decline of $-1.7 \%$ caused by the war in Iraq and the outbreak of the dreaded SARS disease. Such an event with international tourism can be expected and predicted for the current economic crisis.

The forecasts that the authors of this paper agree with (Ritchie et al., 2010; Smeral, 2009; Smeral, 2010; Song, \& Lin, 2010) warn about the decline in world tourist traffic, and the duration of the crisis from 2 to 5 years. The decline in tourist spending will cause a real blow to all activities in the function of tourism. Due to the lack of financial and credit funds, the development of tourism will be absent. Some of the forecasts are summarized below:

The global financial crisis could cost the world tourism market up to a 20 percent drop in total international traffic. Expressed in figures, this would 
mean that in the international tourist movements in 2009 , there could be about 180 million tourists less than 900 million world travelers in 2008 . Destinations far from the initiative markets will suffer the largest decrease (Ružić et al., 2009; Ružić \& Medica, 2010).

The financial crisis will have a severe impact on the activities that serve tourism. Tourists will no longer be able to spend as before, so activities in the function of tourism such as trade, food production, hotels and restaurants are under attack. The reduction in tourist spending will cause an unprecedented recession. Potential tourists will not spend as generously as boredom (Ružić et al., 2009; Ružić \& Medica, 2010; Papatheodorou et al., 2010).

Previous research on the effects of the global economic crisis on tourism is scarce and suggests only the basic directions of possible trends. Thus, the World Tourism Organization - UNWTO (2009), warns that tourism will experience a stronger decline in demand by the end of 2009 and in the first half of next year. In these years, a decline in tourist traffic is expected by an average of 5\% (Ružić et al., 2009; Ružić \& Medica, 2010).

For world tourism, according to the report of the Ministry of Tourism and Sport, (2020, 2021), 2020 is the worst year in history with a drop in international tourist arrivals of 74 percent or about a billion less than in 2019. Continued travel restrictions and other anti-pandemic measures also reduce expectations of recovery in 2021, the World Tourism Organization - UNWTO (2009) reported. Such a decline in world tourism is a direct consequence of declining tourist demand and restrictions on travel around the world.

"The collapse of international travel in 2020 also represents an estimated loss of tourism export revenue of about $\$ 1.3$ trillion more than 11 times the loss recorded during the global economic crisis of 2009. The pandemic has directly jeopardized between 100 and 120 million jobs in tourism, many of which are in small and medium-sized enterprises", the UNWTO (2009) said.

They are aware that a lot has been done to enable safe international travel, but also that the crisis is not over yet because many countries will reintroduce stricter travel restrictions in early 2021 due to the continuation of the pandemic, which includes mandatory testing, quarantine and sometimes complete closure of borders. 
The UNWTO (2009) expects that the gradual introduction of the virus vaccine will help restore consumer confidence, help ease travel restrictions and slowly normalize travel in 2021, but these expectations are still somewhat more cautious than in autumn 2020 and early 2021.

Currently, almost 50 percent of surveyed experts expect 'some' recovery (Kresić \& Mikulić, 2020; Buntu et al., 2021) only in 2022, while 21 percent thought so in October. The remaining half still see opportunities in 2021, which is less than almost 80 percent who, in October 2020, believed in a recovery in 2021, for which they now predict only an increase in domestic tourism and demand for outdoor tourism activities.

Commenting on the results from 2020 by individual regions of the world, the UNWTO emphasizes that the most affected world region was Asia and the Pacific, where international tourist arrivals fell by 84 percent or 300 million compared to 2019. It is also a region that was the first to experience a pandemic, and currently has the highest level of travel restrictions. It is followed by the Middle East with 76 percent fewer international tourist arrivals, and Europe with an annual decline of 71 .

Although Europe had, as they say from the UNWTO (2009), "a small and short-lived revival of tourism in the summer of 2020," it still suffered the largest absolute decline among the world's regions, with more than 500 million fewer international tourists than in 2019.

Meanwhile, 70 percent fewer international tourists came to Africa, and with the smallest drop, of 69 percent, the Americas stands out, because they had slightly better results in the last, fourth quarter of 2020 than in previous quarters.

\section{Methodology}

The research in this paper is based on primary and secondary sources, as well as an approach and methods based on the views of domestic and foreign researchers. Secondary data sources will be used to conduct the research to obtain the necessary information. Secondary data refer to books, scientific and professional articles, online sources of relevant international and domestic authors in the field of tourism in crisis situations. The paper uses descriptive research, and the collected data will be quantitatively and qualitatively analyzed and will be presented in tables and graphs. By descriptive methods of synthesis and analysis, comparisons, the collected 
data are systematized into a logical whole with the aim of providing an overview of the obtained research results.

The research will be conducted in two phases; theoretical and empirical. The first is aimed at exploring the theoretical basis within which the relevant knowledge about the COVID pandemic will be systematized, and related to the emerging global economic crisis and their mutual impact on tourism trends. The empirical research is based on the results of a comparative analysis of tourist trends conducted in the period of the second half of 2019, before the COVID crisis and in 2020, during the COVID crisis.

\section{The aim of the research and hypothesis}

The aim of the research is to analyze the impact of the global economic crisis caused by the pandemic on tourism sector, with a focus on tourist trends (tourist traffic and overnight stays), using Istria as an example.

In accordance with the stated goal of the research and the current knowledge about tourist trends in times of economic crises, the authors set the following hypotheses:

- H1 = The global economic crisis caused by the COVID pandemic will slow down overall tourist traffic (visits and overnight stays)

- $\mathrm{H} 2$ = The global economic crisis caused by the COVID pandemic will have less of an impact on slowing the growth of tourist traffic in destinations close to the initial markets and more from more distant ones.

- H3 = COVID pandemic will cause changes in the choice of location and type of accommodation, where there will be increased interest in accommodation in rural areas, and from accommodation facilities there will be more interest in accommodation in rooms and apartments on family farms, rooms and apartments in households and accommodation facilities in campsites, and least in large hotels in tourist centers.

The research was conducted in a period of two years (2019 and 2020), i.e. before and during the COVID pandemic. The spatial scope of the research refers to the rural and maritime area of Istria, which is located in the northeastern part of the Adriatic Sea on the westernmost and largest peninsula of Croatia. The Istrian peninsula is also the westernmost county of the Republic of Croatia, the closest Mediterranean tourist destination to the countries of Central Europe. The area of the Istrian peninsula belongs to the County of Istria is 2,822 square kilometers, which is $4.98 \%$ of the total area of the Republic of Croatia (Regione Istriana, 2009/10). 
Istria is the leading tourist destination in Croatia. According to available data, in 2019 tourists had at their disposal a total accommodation capacity of 294,339 units (beds and places in camps). Of the stated number of accommodation units, $50 \%$ are places in camps. With the total capacity, the County of Istria participates with $25 \%$ in the total capacities of the Republic of Croatia. In 2019, more than 4.6 million arrivals were realized, which is $25 \%$ of total arrivals in Croatia, and over 28.7 million overnight stays or $32 \%$ of those realized in Croatia.

\section{Results}

To prove the set hypotheses, research was conducted with a focus on the realized tourist and overnight traffic in the year 2020, burdened by the COVID pandemic and the global economic crisis, and the year 2019, before the crisis. Testing of the first hypothesis, that due to the COVID pandemic and the caused global economic crisis, suffered a decline in tourist traffic and overnight stays, will be performed by comparing data on total tourist arrivals and overnight stays at the time of the COVID pandemic in 2020 with preceding year's results. To this end, Table 1 shows the realized turnover of tourists and overnight stays in the Istrian tourist destination in the stated years and by quarters.

Table 1: Realized tourist traffic (tourists and overnight stays, by quarters) before and during the COVID pandemic

\begin{tabular}{|l|r|r|r|}
\hline \multicolumn{1}{|c|}{ Turnover description } & \multicolumn{1}{|c|}{$\mathbf{2 0 1 9}$} & \multicolumn{1}{|c|}{$\mathbf{2 0 2 0}$} & Index 2020/19 \\
\hline Total Visitors & $4,609,799$ & $1,876,999$ & 40 \\
\hline Domestic & 313,216 & 182,804 & 58 \\
\hline Foreign & $4,296,583$ & $1,694,195$ & 39 \\
\hline Total Nights & $28,709,556$ & $13,514,684$ & 47 \\
\hline Domestic & $1,202,043$ & 809,441 & 67 \\
\hline Foreign & $27,507,513$ & $12,705,243$ & 46 \\
\hline
\end{tabular}

Source: Istria County Tourist Board (05 January 2021)

The data from Table 1 show that in the Istrian tourist destination in the crisis period in 2020, there were 60 percent less tourist arrivals and 53 fewer overnight stays than in the same period in 2019, which was rated as a record in terms of tourist traffic. This certainly confirms the thesis that the economic crisis is causing a slowdown in tourist traffic, which is confirmed by this research at the local level on the example of the Istrian tourist destination. 
The COVID pandemic developed rapidly and in waves. It appeared in the Istrian tourist destination at the beginning of 2020, only to reach its peak in March 2020. At that time, due to the intensive spread of the virus, and in order to protect the population, strict measures were introduced on movement, in order to minimize close contacts. Also, at that time, all production and non-production activities ceased to operate, except those that were deemed important for maintaining human life and health. Thus, the pandemic caused increase in unemployment, a drop in production, an unprecedented crisis that lasted until June 2020. Then there was a pause, only to reappear in a similar second wave at the end of the year.

In order to notice the impact of the pandemic with regard to its development during the year, Table 2 shows the realized tourist turnover and overnight stays by quarters.

Table 2: Realized tourist traffic (tourists and overnight stays, by quarters) before and during the COVID pandemic

\begin{tabular}{|c|r|r|r|r|c|c|}
\hline \multirow{2}{*}{ Quarter } & \multicolumn{2}{|c|}{$\mathbf{2 0 1 9}$} & \multicolumn{2}{c|}{$\mathbf{2 0 2 0}$} & \multicolumn{2}{c|}{ Index } \\
\cline { 2 - 7 } & Tourists & \multicolumn{1}{|c|}{ Nights } & \multicolumn{1}{c|}{ Tourists } & Nights & $\mathbf{2 0 2 0 / 1 9}$ & $\mathbf{2 0 2 0} / \mathbf{1 9}$ \\
\hline $1-3$ & 157,076 & 504,905 & 99,294 & 371,299 & 63 & 73 \\
\hline $3-6$ & $1,457,890$ & $7,115,624$ & 295,897 & $1,555,639$ & 20 & 21 \\
\hline $6-9$ & $2,739,007$ & $20,154,845$ & $1,414,512$ & $11,238,181$ & 52 & 56 \\
\hline $9-12$ & 255,835 & 934,184 & 67,296 & 349,565 & 26 & 37 \\
\hline Total & $4,609,808$ & $28,709,558$ & $1,876,999$ & $13,514,684$ & 40 & 47 \\
\hline
\end{tabular}

Source: Istria County Tourist Board (05 January 2021)

The data from Table 2 show the correlation between the spread and growth of the COVID pandemic with its impact on tourism, i.e. on the realization of tourist traffic and overnight stays. In the first quarter, as the pandemic gradually spread both in the narrower area and globally, tourist and overnight traffic experienced the smallest decline. In the second quarter, once the pandemic peaked, the largest decline in tourist traffic and overnight stays was achieved. For the third quarter, in which the threat of the pandemic was declared to have declined, the turnover of tourists and overnight increased significantly, but remained at half of the level of half realized in 2019. In the fourth quarter, a large drop in tourists and overnight stays was recorded again due to the appearance of the second wave of the pandemic, which was more devastating than the first one.

The following table shows the traffic of tourists to the country of arrival before and during the pandemic. These indicators provide an overview of the preferred direction of tourists during the pandemic and crisis. 
Table 3: Overview of tourists by country of arrival before and during the COVID pandemic

\begin{tabular}{|c|r|r|c|}
\hline Country of arrival & Tourists 2019 & Tourists 2020 & Index 2020/2019 \\
\hline Austria & 654,667 & 152,800 & 23 \\
\hline Belgium & 48,397 & 16,742 & 35 \\
\hline Czech Republic & 152,319 & 97,608 & 64 \\
\hline Denmark & 12,919 & 43,203 & 30 \\
\hline France & 64,478 & 13,274 & 21 \\
\hline Italy & 462,910 & 98,559 & 21 \\
\hline Hungary & 129,062 & 40,927 & 32 \\
\hline Netherlands & 171,155 & 32,595 & 19 \\
\hline Germany & $1,059,908$ & 601,905 & 57 \\
\hline Poland & 130,279 & 80,528 & 62 \\
\hline Russia & 46,928 & 5,776 & 12 \\
\hline Slovakia & 68,601 & 21,094 & 31 \\
\hline Slovenia & 605,923 & 352,327 & 58 \\
\hline Serbia & 42,630 & 22,797 & 53 \\
\hline Sweden & 41,048 & 3,607 & 9 \\
\hline Switzerland & 67,303 & 28,746 & 43 \\
\hline UK & 146,201 & 15,272 & 10 \\
\hline Others & 705,071 & 249,239 & 35 \\
\hline Total & $4,609,799$ & $1,876,999$ & 40 \\
\hline
\end{tabular}

Source: Istria County Tourist Board (05 January 2021)

The indicators shown in Table 3 present the tourist traffic of visitors by the country of arrival, which prove the claim that the pandemic caused a greater slowdown in tourist traffic (visitors and overnight stays) from more remote tourist countries (markets), while the decline in tourist traffic from closer initiative tourist countries (markets) slower.

The first claim is proven by a smaller decline in arrivals from neighboring Slovenia, which remained at 58\%, Serbia 53\%, Germany 57\%, the Czech Republic 64\%, compared to the last year's results.

On the other hand, a larger drop in tourist arrivals was realized from more distant destinations; $12 \%$ from Russia, 10\% from Great Britain, 9\% from Sweden, 19\% from the Netherlands, compared to results of 2019.

The following tables present data on the turnover of tourists and overnight stays according to their choice of living space and type of accommodation facility. 
Table 4: Realized tourist traffic (tourists and overnight stays) before and during the pandemic according to the choice of living space

\begin{tabular}{|c|c|c|c|c|c|c|}
\hline \multirow{2}{*}{ Destination } & \multicolumn{2}{|c|}{2019} & \multicolumn{2}{|c|}{2020} & \multicolumn{2}{|c|}{ Index } \\
\hline & Toursist & Nights & Toursist & Nights & $2020 / 19$ & $2020 / 19$ \\
\hline Bale & 55,726 & 362,458 & 27,596 & 193,112 & 50 & 53 \\
\hline Barban & 12,834 & 105,147 & 7,874 & 68,978 & 61 & 66 \\
\hline Brtonigla & 76,132 & 627,770 & 34,855 & 320,748 & 46 & 51 \\
\hline Buje & 45,290 & 213,777 & 16,324 & 83,092 & 36 & 39 \\
\hline Buzet & 18,728 & 62,858 & 7,308 & 34,202 & 39 & 54 \\
\hline Grožnjan & 4,869 & 22,542 & 2,889 & 17,079 & 59 & 76 \\
\hline Kanfanar & 8,608 & 70,847 & 5,464 & 52,244 & 63 & 74 \\
\hline Kaštelir-Labinc & 9,375 & 85,479 & 6,589 & 62,793 & 70 & 73 \\
\hline Kršan & 8,963 & 70,300 & 5,621 & 57,330 & 63 & 82 \\
\hline Ližnjan & 35,240 & 290,112 & 21,212 & 193,650 & 60 & 67 \\
\hline Marčana & 47,914 & 382,632 & 27,186 & 243,819 & 57 & 64 \\
\hline Motovun & 23,931 & 54,850 & 9,942 & 28,286 & 42 & 52 \\
\hline Oprtalj & 15,304 & 54,314 & 4,469 & 21,308 & 29 & 39 \\
\hline Pazin & 40,762 & 300,243 & 28,131 & 222,419 & 69 & 74 \\
\hline Raša & 45,126 & 357,169 & 24,581 & 215,513 & 54 & 60 \\
\hline Sveta Nedelja & 12,067 & 110,266 & 8,422 & 80,153 & 70 & 73 \\
\hline Svetvinčenat & 16,227 & 141,771 & 12,363 & 109,457 & 76 & 77 \\
\hline Višnjan & 11,585 & 89,177 & 7,259 & 61,906 & 63 & 69 \\
\hline Vižinada & 6,316 & 49,477 & 4,666 & 39,446 & 74 & 80 \\
\hline Vodnjan & 57,366 & 684,474 & 43,454 & 532,307 & 76 & 78 \\
\hline Žminj & 9,856 & 85,182 & 6,878 & 59,374 & 70 & 70 \\
\hline Rural areas & 562,219 & $4,220,845$ & 313,083 & $2,697,216$ & 63 & 55 \\
\hline Fažana & 144,439 & $1,055,382$ & 67,615 & 520,586 & 47 & 49 \\
\hline Funtana & 237,206 & $1,721,331$ & 99,107 & 743,193 & 42 & 43 \\
\hline Labin & 245,272 & $1,440,277$ & 71,231 & 453,250 & 29 & 31 \\
\hline Medulin & 426,221 & $2,765,651$ & 195,667 & $1,448,537$ & 46 & 52 \\
\hline Novigrad & 230,296 & $1,331,891$ & 104,327 & 641,074 & 45 & 48 \\
\hline Poreč & 589,120 & $3,485,233$ & 203,953 & $1,388,144$ & 35 & 40 \\
\hline Pula & 445,623 & $2,174,652$ & 149,184 & 855,878 & 33 & 39 \\
\hline Rovinj & 721,060 & $4,011,658$ & 294,562 & $1,846,127$ & 41 & 46 \\
\hline Tar-Vabriga & 256,373 & $1,973,775$ & 90,082 & 804,826 & 35 & 41 \\
\hline Umag & 505,155 & $2,724,542$ & 183,328 & $1,273,200$ & 36 & 47 \\
\hline Vrsar & 221,560 & $1,634,030$ & 87,087 & 712,854 & 39 & 44 \\
\hline Nautika & 25,255 & 170,289 & 17,773 & 129,799 & 70 & 76 \\
\hline Maritime space & $4,047,580$ & $24,488,711$ & $1,563,916$ & $10,817,468$ & 44 & 38 \\
\hline Total Istra & $4,609,799$ & $28,709,556$ & $1,876,999$ & $13,514,684$ & 40 & 47 \\
\hline
\end{tabular}

Source: Istria County Tourist Board (05 January 2021) 
The data in Table 4 show the realized tourist traffic related to the rural area and the maritime area. From the above indicators it is noticeable that during the COVID pandemic rural (63\%) and maritime areas $(44 \%)$ are prefereable, which is understandable because the area is less crowded, allowing social distancing and lower risk of infection. In addition to the above, the rural area of Istria provides tourists with a special quality of stay, as research has shown (Ružić et al., 2011; Ružić \& Amidžić, 2018). Table 5 presents data on the realized tourist traffic according to the choice of accommodation facility.

Table 5: Realized tourist traffic (tourists and overnight stays) before and during the pandemic according to the choice of accommodation facility

\begin{tabular}{|c|r|r|r|r|r|c|}
\hline \multirow{2}{*}{$\begin{array}{c}\text { Type of } \\
\text { accomodation }\end{array}$} & \multicolumn{2}{|c|}{2019} & \multicolumn{2}{c|}{2020} & \multicolumn{2}{c|}{ Index } \\
\cline { 2 - 7 } & Toursits & Nights & Toursits & Nights & $\begin{array}{c}2020 / \\
2019\end{array}$ & $\begin{array}{c}2020 / \\
2019\end{array}$ \\
\hline Hotels & $1,727,443$ & $7,976,149$ & 447,991 & $2,156,510$ & 26 & 27 \\
\hline Camps & $1,338,884$ & $9,741,004$ & 573,245 & $4,323,902$ & 43 & 44 \\
\hline $\begin{array}{c}\text { Private } \\
\text { accomodation }\end{array}$ & 94,592 & $2,039,988$ & 118,102 & $1,834,366$ & 125 & 89 \\
\hline $\begin{array}{c}\text { Household } \\
\text { facilities }\end{array}$ & 2,780 & 13,567 & 1,835 & 10,781 & 66 & 79 \\
\hline Family farms & $1,076,537$ & $6,982,096$ & 567,117 & $4,161,927$ & 53 & 59 \\
\hline Others & 369,563 & $1,956,752$ & 168,709 & $1,027,198$ & 45 & 52 \\
\hline Total & $4,609,799$ & $28,709,556$ & $1,876,999$ & $13,514,684$ & 40 & 47 \\
\hline
\end{tabular}

Source: Istria County Tourist Board (05 January 2021)

Based on the data presented in Table 5, the preference for selecting the facility for accommodation required in the COVID pandemic was investigated. According to the data in Table 5, it can be seen that tourists mostly preferred accommodation in facilities on family farms (66\%), households $(53 \%)$ and camps $(43 \%)$. The preference of tourists for accommodation in hotels is the lowest (26\%), as the higher concentration of people indoors allows greater spread of the virus.

\section{Conclusion and recommendations}

The research presented in this paper points to the fact that the process of globalization has also affected tourism. The appearance of the COVID pandemic was followed by the global economic crisis which affected the world economy with the consequences of falling production, rising unemployment, and the lack of financial resources impeding development 
and liquidity. This is also reflected in tourism, causing a number of adverse consequences, such as the decline in the number of visitors and overnight stays and tourist spending.

This paper examines the assumptions about the movement of physical traffic (tourists and overnight stays) in tourism during the COVID pandemic at the local level, using Istria as an example.

A study conducted on the tourism activity of Istria found that in the year of the COVID pandemic (2020) there was a slowdown in visitor and overnight stays to (40\% of tourists, $47 \%$ of overnight stays), compared to the results form 2019. This confirms the first assumption which claims that in general, in times of global economic crises, there is a slowdown in tourist traffic, which is confirmed at the level of the Istrian tourist destination.

Given that this is a specific global economic crisis caused by the COVID pandemic, research and special assumptions are imposed that there will be a greater slowdown in the arrival of tourists from more remote tourist destinations, and that there will be changes in the choice of accommodation and living space tourist.

The assumption, which claims that a decline in the number of visitors and overnight stays will be greater for those arriving from more distant locations, stands and has been fully proven on the example of Istrian tourism. The first was proven by a smaller drop in arrivals from neighboring Slovenia, which remained at 58\%, Serbia 53\%, Germany 57\%, Czech Republic 64\%, of 2019 level. On the other hand, a larger drop in tourist arrivals was realized for those arriving from Russia (12\%), Great Britain (10\%), Sweden (9\%), and the Netherlands (19\%).

The assumption that there will be changes in the preference for the choice of accommodation and tourist accommodation is also proven by the example of Istrian tourism. The results of the survey of tourists' preferences regarding accommodation and space show that tourists preferred accommodation in facilities on family farms $(66 \%)$, private households (53\%) and camps (43\%). The preference of tourists for accommodation in hotels is the lowest (26\%), which is understandable due to the higher concentration of people indoors, which significantly increases the spread of the infection. Also, it is noticeable that during the COVID pandemic, visitors preferred rural areas $(63 \%)$ to the maritime (44\%). 
According to the obtained research results, marketing and promotional activities are recommended, aimed at those within a closer territorial vicinitiy, as this would lead to a larger influx of tourists. It is also necessary to adjust the offer of accommodation, food, entertainment and leisure to the preferences of tourists by adjusting the supply of services away from large tourist centers towards rural areas, famility farms and the likes.

\section{References}

1. Aramberri, J. (2008). The future of Tourism and globalization: some criticl remarks. Futures, Vol. 35, No. 6, 367-376.

2. Buntu, M., E., Paud, M. S., Azinuddin, M., Syamsu, A., Rijal, S., Ridwan M. (2021). The Impacts of the Covid-19 Pandemic on the Tourism Economy in South Sulawesi, Indonesia. Psychology and Education Journal, Vol. 59, No. 2, 30-45.

3. Istria County Tourist Board, (2021), https://www.istra.hr/hr/businessinformation/istra-u-medijima/statistika/arhiva-2020, (3 March 2021).

4. Kresić, D., Mikulić, J. (2020). Scenarij faznog pristupanja oporavka turističkog tržišta nakon Covid 19 pandemije. [A scenario of a phased approach to the recovery of the tourism market after the Covid 19 pandemic]. Institut za turizam Zagreb, Hrvatska.

5. Ministry of Tourism and Sport, (2020), Turizam i Covid-19 - Pitanje od 1000 milijardi eura: Koliko će trajati kriza turizma uzrokovana COVID-19 pandemijom [Tourism and Covid-19 - The $€$ 1,000 billion question: How long will the tourism crisis caused by the COVID-19 pandemic last], https://mints.gov.hr/vijesti/turizam-i-Covid-19-pitanje-od-1000-milijardieura-koliko-ce-trajati-kriza-turizma-uzrokovana-Covid-19pandemijom/21889, (3 March 2021).

6. Ministry of Tourism and Sport, (2021), Za turizam 2020. povijesno najgora godina - milijardu turista manje putovalo svijetom [For tourism in 2020, historically the worst year - a billion fewer tourists traveled the world], https://mint.gov.hr/vijesti/za-turizam-2020-povijesno-najgoragodina-milijardu-turista-manje-putovalo-svijetom/22263, (3 March 2021). 
7. Papatheodorou, A., Rosselló, J., Xiao, H. (2010). Global economic crisis and tourism: Consequences and perspectives. Journal of Travel Research, Vol. 49, No.1, 39-45.

8. Regione istriana, (2009/10), Geographic data, http://stariweb.istraistria.hr/index.php?id=610, (3 March 2021).

9. Ritchie, J. B., Molinar, C. M., Frechtling, D. C. (2010). Impacts of the world recession and economic crisis on tourism: North America. Journal of Travel Research, Vol. 49, No. 1, 5-15.

10. Ružić, P., Dropulić, M., Medica, I. (2009). Impacts of Global Economic Crisis on Worlds Tourism Trends. International scientific Conference, The Influence of Global Economic Recesion on Tourism, Ohrid Macedonija, 102-103.

11. Ružić, P., Medica, I. (2010). Tourist Movements and Expenditure in Istria in Conditions of Global Economic Crisis, International scientific Conference, Turisam $i$ hotelska industrija 2010. Novi trendovi u turističkom i hotelskom menadžmentu, Opatija, Hrvatska, 191-201.

12. Ružić, P. Amidžić, D., (2018). Identification and analysis of indicators on sustainable tourism development of Istria Croatia. TISC - Tourism International Scientific Conference, Vrnjačka Banja, 134-152.

13. Ružić, P.; Amidžić, D., Ružić, T. (2011). Ocjena atraktivnosti i projektiranje ruralne turističke destinacije Istre. [Assessment of attractiveness and design of a rural tourist destination in Istria] "Znanstveno-stručni skup s međunarodnim sudjelovanjem, Projekti $i$ projektni menadžment", Zaprešić/Zagreb, 761-771.

14. Smeral, E. (2009). The impact of the financial and economic crisis on European tourism. Journal of Travel Research, Vol. 48, No. 1, 3-13.

15. Smeral, E. (2010). Impacts of the world recession and economic crisis on tourism: Forecasts and potential risks. Journal of Travel Research, Vol. 49, No. 1, 31-38.

16. Song, H., Lin, S. (2010). Impacts of the financial and economic crisis on tourism in Asia. Journal of Travel Research, Vol. 49, No. 1, 16-30. 
17. World Tourism Organization - UNWTO (2009). Tourism Highlights, Edition 2009, http://tourlib.net/wto/WTO_highlights_2009.pdf, (3 March 2021). 